\title{
Incidence of venereal diseases in the Netherlands
}

\author{
H. BIJKERK
}

Geneeskundige Hoofinspectie van de Volksgezondheid, Leidschendam, The Netherlands

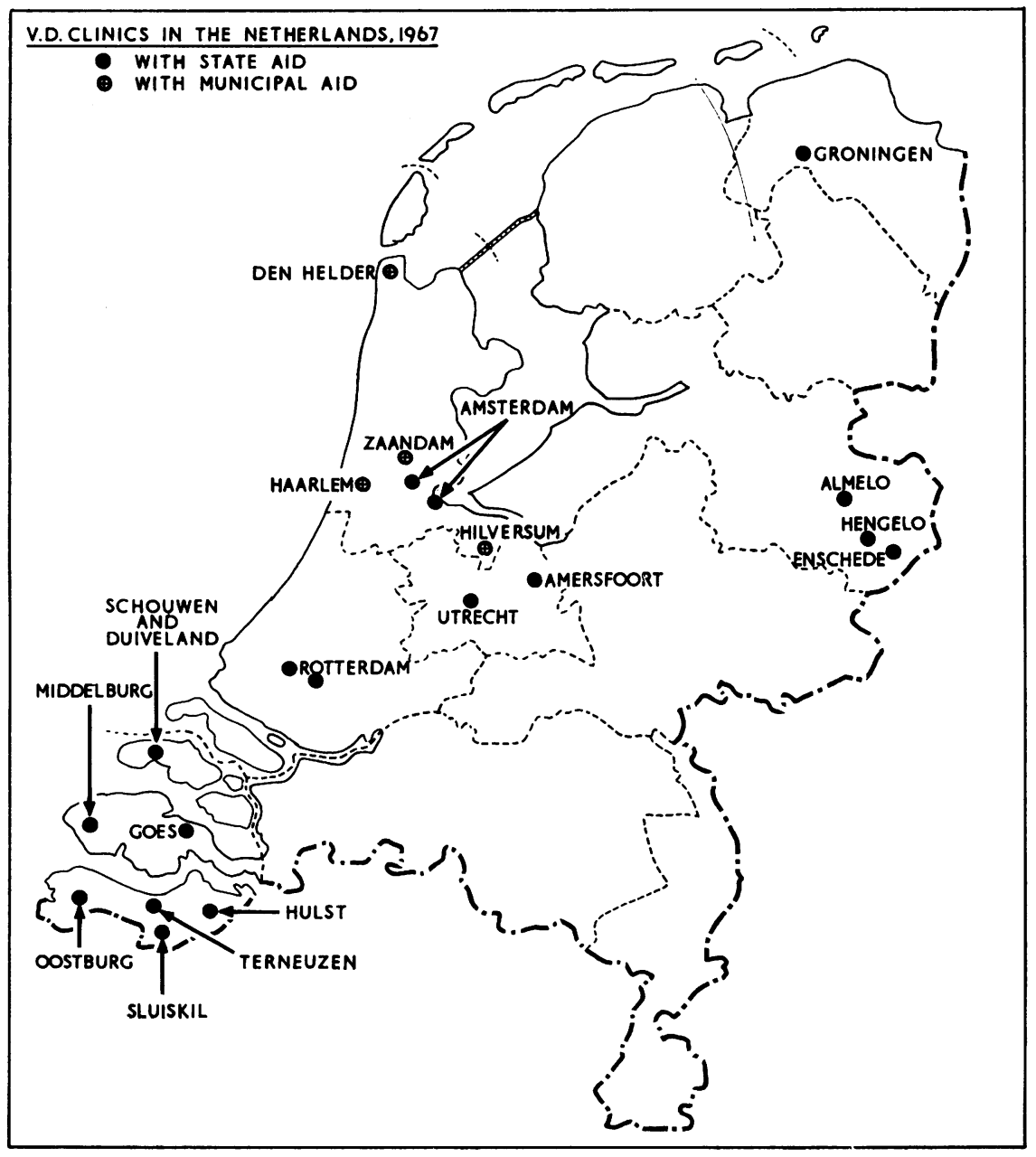

FIG. 1 Map of the Netherlands, showing location of V.D. clinics, 1967

VENEREAL diseases are not notifiable in the Netherlands, but the following data have been obtained from the annual reports of the V.D. clinics, from retrospective enquiries into the incidence of primary and secondary syphilis in general practice for the years 1959,1963 , and 1967, and from a prospective enquiry in dermatological practice for 1967 only.
Until 1959-60 there were many V.D. clinics throughout the Netherlands, but it was then decided to close most of them because they were receiving so few new cases. In 1967 there were seventeen stateaided clinics and four municipal clinics (Fig. 1). In recent years their statistics have thus become less and less representative of the incidence of V.D. in the 
country as a whole, and the figures supplied by the general practitioners and dermatologists are therefore more in accordance with the actual situation.

\section{Results of retrospective enquiries among general practitioners for the years 1959, 1963, and 1967}

\section{Response to the enquiry}

The response proved to be excellent; 88,92 , and 89 per cent. of the general practitioners collaborated in the enquiry for the years 1959, 1963, and 1967 respectively. Table I gives the number of patients with primary or secondary syphilis. In 1963, as compared with 1959, there was an increase of over 130 per cent., and in 1967, as compared with 1963, an increase of 40 per cent. It is probable, however, that many cases of 'primary or secondary syphilis' reported by general practitioners were in reality cases of late latent or tertiary syphilis. The twelve general practitioners in the province of Friesland who together reported fifteen patients with primary or secondary syphilis for 1967 were asked by telephone for further diagnostic information, and only one patient ultimately proved to have primary syphilis. The remaining fourteen patients included no less than ten cases of late latent or tertiary syphilis, three of early latent syphilis, and one (an adult woman) of congenital syphilis. It seems unlikely that the twelve practitioners in Friesland differed in their diagnostic standards from their colleagues elsewhere in the country.

$T A B L E$ I Response by general practitioners and reported cases of syphilis, 1959, 1963, 1967

\begin{tabular}{|c|c|c|c|c|c|}
\hline \multirow{2}{*}{$Y c x r$} & \multirow{2}{*}{$\begin{array}{l}\text { Total } \\
\text { practitioners }\end{array}$} & \multicolumn{2}{|c|}{ Response } & \multicolumn{2}{|c|}{$\begin{array}{l}\text { Primary and secondary } \\
\text { syphilis }\end{array}$} \\
\hline & & No. & Per cent. & No. & Rate per 100,000 \\
\hline 1959 & 4,132 & 3,642 & 88 & 204 & $1 \cdot 8$ \\
\hline 1963 & 4,359 & 4,025 & 92 & 472 & 3.9 \\
\hline 1967 & 4,408 & 3,932 & 89 & 660 & $5 \cdot 2$ \\
\hline
\end{tabular}

In setting up these enquiries we perhaps assumed too readily that the general practitioner is sufficiently familiar with what is meant by primary or secondary syphilis. The explanation given on the questionnaire should have been clearer on this point. Despite the shortcomings inherent in such retrospective enquiries, our results indicate that the incidence of early syphilis, and probably also that of gonorrhoea, is still increasing in the Netherlands.
Distribution of patients with primary or secondary syphilis in general practice

Table II shows that the number of general practitioners with cases of syphilis in their practice rose from 149 (4 per cent.) in 1959 to 270 (7 per cent.) in 1963 , and to 400 (10 per cent.) in 1967. This increase was observed in all provinces. Table III shows the number of general practitioners who reported one or more cases of syphilis. Of the $\mathbf{4 0 0}$ who reported cases in 1967, 280 (70 per cent.) had observed one case and 352 (88 per cent.) not more than two cases.

TABLE II General practitioners with cases of syphilis

\begin{tabular}{|c|c|c|c|c|c|}
\hline \multirow{3}{*}{ Year } & \multirow{3}{*}{$\begin{array}{l}\text { Total number } \\
\text { responding }\end{array}$} & \multicolumn{4}{|c|}{ General practitioners } \\
\hline & & \multicolumn{2}{|c|}{ Without cases } & \multicolumn{2}{|c|}{ With cases } \\
\hline & & No. & Per cent. & No. & Per cent. \\
\hline 1959 & 3,642 & 3,493 & 96 & 149 & 4 \\
\hline 1963 & 4,025 & 3,755 & 93 & 270 & 7 \\
\hline 1967 & 3,932 & 3,532 & 90 & 400 & 10 \\
\hline
\end{tabular}

TABLE II I General practitioners reporting cases of syphilis, 1967

\begin{tabular}{ll}
\hline No. of patients & No. of practices \\
\hline 1 & 280 (70 per cent.) \\
2 & $72 \quad(18$ per cent. $)$ \\
\hline 3 & 23 \\
4 & 10 \\
5 & 4 \\
7 & 1 \\
9 & 1 \\
10 & 1 \\
21 & 1 \\
26 & 1 \\
\hline Total & 400 \\
\hline
\end{tabular}

Cases of primary or secondary syphilis, by age and sex (Table IV, opposite)

The ratio between male and female patients $(2 \cdot 2: 1$ in $1959,4 \cdot 0: 1$ in 1963 , and $3 \cdot 2: 1$ in 1967) rose in 1963 and fell again in 1967.

The age distribution shows that in the teenage $\mathbb{D}$ group (15 to 19 years) there was an increase in accordance with the average national increase, but this increase occurred almost entirely among the boys. Among patients aged between 20 and 29 years the age-specific rate per 100,000 has remained constant; but the males show a decrease and the females an increase. In those aged between 30 and 39 years the 8 number of patients has clearly increased, and for this the male patients are responsible. The group aged 
TABLE IV Patients with primary or secondary syphilis, by age and sex

\begin{tabular}{|c|c|c|c|c|c|c|c|c|c|c|c|}
\hline$\frac{\text { Year }}{\text { Sex }}$ & & & \multicolumn{3}{|l|}{1959} & \multicolumn{3}{|l|}{1963} & \multicolumn{3}{|l|}{1967} \\
\hline \multirow[t]{2}{*}{ No. of cases } & \multirow[t]{2}{*}{ Age group (yrs) } & $\begin{array}{l}0-14 \\
15-19 \\
20-29 \\
30-39 \\
40-49 \\
50 \text { and over } \\
\text { Not known }\end{array}$ & $\begin{array}{r}5 \\
10 \\
68 \\
30 \\
15 \\
12 \\
-\end{array}$ & $\begin{array}{r}7 \\
9 \\
18 \\
22 \\
5 \\
3 \\
-\end{array}$ & $\begin{array}{l}12 \\
19 \\
86 \\
52 \\
20 \\
15 \\
-\end{array}$ & $\begin{array}{r}-\overline{18} \\
187 \\
96 \\
29 \\
22 \\
26\end{array}$ & $\begin{array}{r}\overline{10} \\
38 \\
31 \\
9 \\
6 \\
-\end{array}$ & $\begin{array}{r}\overline{28} \\
225 \\
127 \\
38 \\
28 \\
26\end{array}$ & $\begin{array}{r}\overline{27} \\
190 \\
135 \\
56 \\
50 \\
45\end{array}$ & $\begin{array}{r}1 \\
11 \\
62 \\
30 \\
26 \\
26 \\
1\end{array}$ & $\begin{array}{r}1 \\
38 \\
252 \\
165 \\
82 \\
76 \\
46\end{array}$ \\
\hline & & Total & 140 & 64 & 204 & 378 & 94 & 472 & 503 & 157 & 660 \\
\hline \multicolumn{3}{|l|}{ Sex ratio } & \multicolumn{3}{|c|}{$2 \cdot 2: 1$} & \multicolumn{3}{|c|}{$4 \cdot 0: 1$} & \multicolumn{3}{|c|}{$3 \cdot 2: 1$} \\
\hline $\begin{array}{l}\text { Age-specific } \\
\text { rates per } 100,000 \\
\text { population }\end{array}$ & Age group (yrs) & $\begin{array}{l}0-14 \\
15-19 \\
20-29 \\
30-39 \\
40-49 \\
50 \text { and over }\end{array}$ & $\begin{array}{l}0 \cdot 3 \\
2 \cdot 2 \\
8 \cdot 6 \\
4 \cdot 0 \\
2 \cdot 3 \\
1 \cdot 0\end{array}$ & $\begin{array}{l}0.4 \\
2 \cdot 1 \\
2 \cdot 3 \\
2 \cdot 9 \\
0 \cdot 7 \\
0 \cdot 2\end{array}$ & $\begin{array}{l}0.4 \\
2 \cdot 1 \\
5 \cdot 5 \\
3 \cdot 4 \\
1 \cdot 5 \\
0 \cdot 6\end{array}$ & $\begin{array}{r} \\
3 \cdot 2 \\
22 \cdot 7 \\
12 \cdot 6 \\
4 \cdot 3 \\
1 \cdot 6\end{array}$ & $\begin{array}{l}- \\
1.9 \\
4 \cdot 8 \\
4 \cdot 0 \\
1 \cdot 3 \\
0 \cdot 4\end{array}$ & \begin{tabular}{r|r|}
2.5 \\
$13 \cdot 8$ \\
$8 \cdot 3$ \\
$2 \cdot 7$ \\
1.0
\end{tabular} & $\begin{array}{r}- \\
4 \cdot 6 \\
19 \cdot 4 \\
17 \cdot 1 \\
7 \cdot 8 \\
3 \cdot 5\end{array}$ & $\begin{array}{l}0.0 \\
2.0 \\
6.8 \\
4.0 \\
3.5 \\
1.6\end{array}$ & $\begin{array}{r}0.0 \\
3 \cdot 3 \\
13 \cdot 3 \\
10 \cdot 7 \\
5 \cdot 6 \\
2 \cdot 5\end{array}$ \\
\hline
\end{tabular}

40 years and over shows the greatest relative increase, that in women exceeding that in men.

\section{Referral of patients with V.D. to dermatologists and readiness of general practitioners to co-operate in the control of V.D.}

Questions designed to investigate to what extent the general practitioners refer or would refer patients with definite or suspected primary or secondary syphilis or gonorrhoea to the dermatologist were included in the 1967 questionnaire. Table $\mathrm{V}$ shows that 88.7 per cent. of general practitioners 'as a rule' refer syphilis patients to the dermatologist, 5.7 per cent. 'sometimes', and $2 \cdot 1$ per cent. 'never'. The percentages were quite different with regard to the referral of gonorrhoea patients: 'as a rule' 37.6 per cent., 'sometimes' 35 per cent., 'never' 26 per cent.

TABLE $\mathbf{R}$ Referral of cases of syphilis and gonorrhoea to a dermatologist *

\begin{tabular}{|c|c|c|c|c|}
\hline $\begin{array}{l}\text { Referral of patients to a } \\
\text { dermatologist }\end{array}$ & $\begin{array}{l}\text { Syphilis } \\
\text { No. }\end{array}$ & Per cent. & $\begin{array}{l}\text { Gonor } \\
\text { No. }\end{array}$ & $\begin{array}{l}\text { hoea } \\
\text { Per cent. }\end{array}$ \\
\hline $\begin{array}{l}\text { As a rule } \\
\text { Sometimes } \\
\text { Never } \\
\text { No opinion or not known }\end{array}$ & $\begin{array}{r}3,541 \\
227 \\
83 \\
138\end{array}$ & $\begin{array}{r}88 \cdot 7 \\
5 \cdot 7 \\
2 \cdot 1 \\
3 \cdot 5\end{array}$ & $\begin{array}{r}1,501 \\
1,395 \\
1,038 \\
55\end{array}$ & $\begin{array}{r}37 \cdot 6 \\
35 \cdot 0 \\
26 \cdot 0 \\
1 \cdot 4\end{array}$ \\
\hline otal & 3,989 & 100 & 3,989 & 100 \\
\hline
\end{tabular}

*Including the replies of 57 G.P.s representing a random sample of 12 per cent. among those not responding.

The question about the readiness of the general practitioner to co-operate with an organization for the control of V.D. (Table VI) was posed very carefully. Assuming that in this connection full allowance will be made for the wishes of the patient and the doctor,
85.1 per cent. of the general practitioners were willing in principle to co-operate in this way, 7.5 per cent. rejected such co-operation, and 7.4 per cent. had no opinion or did not answer the question.

TABLE VI Willingness of general practitioners to co-operate with an organization for the control of venereal diseases ${ }^{\star}$

Willing to co-operate

\begin{tabular}{ll} 
Practitioners & \\
\hline No. & Per cent. \\
\hline 3,394 & $85 \cdot 1$ \\
299 & $7 \cdot 5$ \\
296 & $7 \cdot 4$ \\
\hline 3,989 & 100
\end{tabular}

Yes

No opinion or not known

Total

3,989

sample of

*Including the replies of 57 G.P.s represen
12 per cent. among those not responding.

Diagnosis of gonorrhoea and performance of serological tests for syphilis

There was a surprisingly good response to this question, which may have been a rather awkward one for the general practitioner. Table VII shows that $25 \cdot 6$ per cent. of general practitioners 'as a rule' based their diagnosis of gonorrhoea exclusively on clinical signs and history. This percentage is highest $(40.7$ per cent.) among those who 'as a rule' refer patients with actual or suspected gonorrhoea to a specialist, and lowest (13.7 per cent.) among those who do not or would not do so. These results are not surprising. Among the first group of general practitioners there will be a greater inclination to leave the diagnosis to the dermatologist than among the latter group. $62 \cdot 4$ per cent. of general practitioners stated that their diagnosis of gonorrhoea was 'as a rule' based on the 
TABLE VII Referral of patients with gonorrhoea to a dermatologist, diagnosis of gonorrhoea, and serological tests for syphilis in patients with gonorrhoea ${ }^{\star}$

\begin{tabular}{|c|c|c|c|c|c|c|c|}
\hline \multicolumn{3}{|c|}{ Percentage referring gonorrhoea patients to a dermatologist } & \multirow{2}{*}{$\begin{array}{c}\text { As a rule } \\
40.7 \\
41.5 \\
2.0 \\
12.9 \\
2.9\end{array}$} & \multirow{2}{*}{$\begin{array}{c}\text { Sometimes } \\
19.3 \\
73.1 \\
4.5 \\
3.0 \\
0.1\end{array}$} & \multirow{2}{*}{$\begin{array}{r}\text { Never } \\
13.7 \\
80.7 \\
3.6 \\
1.6 \\
0.4\end{array}$} & \multirow{2}{*}{$\begin{array}{l}\begin{array}{l}\text { No opinion } \\
\text { or not known }\end{array} \\
1.8 \\
14.5 \\
1.8 \\
36.4 \\
45.5\end{array}$} & \multirow{2}{*}{$\begin{array}{r}\text { Total } \\
25 \cdot 6 \\
62.4 \\
3.3 \\
6.8 \\
1.8\end{array}$} \\
\hline Diagnosis of gonorrhoea & $\begin{array}{l}\text { 1. Clinical s } \\
\text { 2. Clinical s } \\
\text { 3. Combina } \\
\text { No experien } \\
\text { Not known }\end{array}$ & $\begin{array}{l}\text { ory } \\
\text { and smear } \\
2\end{array}$ & & & & & \\
\hline & Total & $\begin{array}{l}\text { Per cent. } \\
\text { No. }\end{array}$ & $\begin{array}{r}100 \\
1,501\end{array}$ & $\begin{array}{r}100 \\
1,395\end{array}$ & $\begin{array}{r}100 \\
1,038\end{array}$ & $\begin{array}{r}100 \\
55\end{array}$ & $\begin{array}{r}100 \\
3,989\end{array}$ \\
\hline \multirow[t]{2}{*}{$\begin{array}{l}\text { Serological tests for syphilis } \\
\text { performed on patients with } \\
\text { gonorrhoea }\end{array}$} & $\begin{array}{l}\text { As a rule } \\
\text { Sometimes } \\
\text { Never } \\
\text { No opinion } \\
\text { Not known }\end{array}$ & & $\begin{array}{r}50 \cdot 8 \\
5 \cdot 5 \\
6 \cdot 9 \\
9 \cdot 5 \\
27 \cdot 3\end{array}$ & $\begin{array}{r}52 \cdot 1 \\
27 \cdot 5 \\
18 \cdot 1 \\
1.5 \\
0.7\end{array}$ & $\begin{array}{r}52.7 \\
25.0 \\
20.5 \\
1.3 \\
0.6\end{array}$ & $\begin{array}{r}14.5 \\
3.6 \\
3.6 \\
29 \cdot 1 \\
49 \cdot 1\end{array}$ & $\begin{array}{r}51.2 \\
18.3 \\
14.3 \\
4.8 \\
11.4\end{array}$ \\
\hline & Total & $\begin{array}{l}\text { Per cent. } \\
\text { No. }\end{array}$ & $\begin{array}{r}100 \\
1,501\end{array}$ & $\begin{array}{r}100 \\
1,395\end{array}$ & $\begin{array}{r}100 \\
1,038\end{array}$ & $\begin{array}{r}100 \\
55\end{array}$ & $\begin{array}{r}100 \\
3,989\end{array}$ \\
\hline
\end{tabular}

^Including the replies of 57 G.P.s representing a random sample of 12 per cent. of those not responding.

clinical signs, history, and smear. The number who stated that they had no experience in the diagnosis of gonorrhoea was very small ( 6.8 per cent.). Table VII further shows that $51 \cdot 2$ per cent. of general practitioners 'as a rule' have a serological test for syphilis performed on patients with actual or suspected gonorrhoea who are not referred to a dermatologist. 18.3 per cent. of general practitioners 'sometimes' have a serological test performed on such patients, and 14.3 per cent. 'never'.

\section{Results of a prospective enquiry among dermatologists for the year 1967}

In December, 1966, all dermatologists were asked to complete a questionnaire for each of their patients with early syphilis* and/or gonorrhoea during 1967

*Including early latent syphilis: no clinical signs, serologically positive, infection contracted less than 5 years ago. and to send it to the Chief Medical Officer of Health. Their response is analysed in Table VIII.

During the first quarter of 1968, those who had not responded were contacted by telephone in an endeavour to obtain at least an approximate impression of the numbers of their patients. In this way it proved possible to obtain data from all but two practising dermatologists.

If we compare these data with the information obtained from the general practitioners about their referral of patients to the dermatologists, it is clear that the latter gives a more accurate picture of the situation in the Netherlands with regard to early syphilis than with regard to gonorrhoea.

\section{Response to the enquiry}

Some dermatologists forwarded data in their capacity as Head of an Out-Patients Clinic for Dermatology

TABLE VIII Response by dermatologists

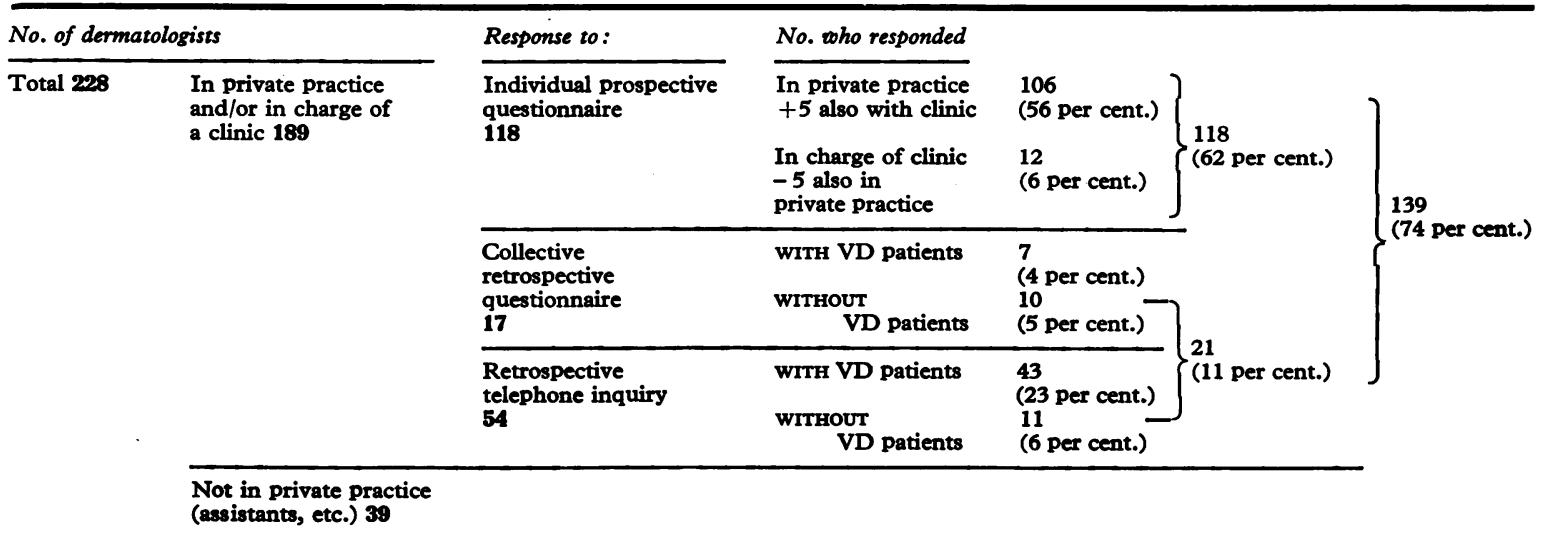


and Venereal Diseases. Seventeen out-patient clinics collaborated in this way. The completeness of the response is not easy to assess, but we have assumed that the respondents kept up their answers to the questionnaire consistently during 1967 . The number of cases reported each month fluctuated somewhat, but there is no sign of a downward trend that might suggest 'enquiry fatigue'. Of the 228 dermatologists not registered as 'retired' by the Chief Medical Officer of Health, 106 (46 per cent.) collaborated in the enquiry from their private practice and twelve (5 per cent.) solely as Head of an Out-Patients Clinic. Five Heads of Out-Patient Clinics also reported separately on their cases in private practice. At first it seemed rather disappointing that only half (51 per cent.) had taken part but this difficulty was largely overcome.

To find out the extent of the number of 'missed' patients, the dermatologists who had co-operated during 1967 were requested to provide data on a 'collective' questionnaire. Seventeen complied with this request, and the other 93 were questioned by telephone. The response to these retrospective enquiries converted our initial disappointment into what we feel to be justified optimism about the value of the 'prospective' enquiry. Table VIII shows that, of the 228 dermatologists, 39 proved not to have a private practice and 21 ( 11 per cent.) of the remaining 189 stated that they had seen no patients with early syphilis and/or gonorrhoea in their practice in 1967. Working on the hypothesis that the dermatologists who returned questionnaires kept this up consistently, it may be concluded that 139 ( 74 per cent.) including the 21 who asserted that they saw no patients with V.D. supplied complete data. This means that, for the year 1967, a full statement of the number of cases of syphilis and gonorrhoea was obtained from 74 per cent. of dermatological specialists. It seems reasonable to assume that the situation reported would be the same in the other 26 per cent. of practices.

\section{Number of V.D. patients reported}

Table IX shows that, of the 3,683 patients reported by the dermatologists, 314 ( 8.5 per cent.) were suffering from primary or secondary syphilis, 92 (2.5 per cent.) from early latent syphilis, 3,247 (88.2 per cent.) from gonorrhoea, and thirty ( 0.8 per cent.)

TABLE IX Number of patients reported by dermatologists

\begin{tabular}{llrr}
\hline Total & Primary or secondary syphilis & 314 & $(8.5$ per cent. $)$ \\
patients & Early latent syphilis & 92 & $(2.5$ per cent. $)$ \\
3,683 & Gonorrhoea & 3,247 & $(88.2$ per cent. \\
Mixed infections & 30 & $(0.8$ per cent. $)$ \\
\hline
\end{tabular}

from a mixed infection. In Table $X$, the 3,683 patients are analysed by nationality and domicile, and also by sex, 2,656 (72 per cent.) being Dutch and 1,027 (28 per cent.) foreigners.

Of the 2,656 Dutch patients, 74 per cent. are males and 26 per cent. females. The 1,027 foreign patients (only 2 per cent. females) may be further subdivided

\section{TABLE X Patients with venereal disease, by nationality} and sex

\begin{tabular}{|c|c|c|c|c|c|}
\hline Total & Nationality & Domicile & Sex & No. & Per cent. \\
\hline \multirow[t]{4}{*}{3,683} & $\begin{array}{l}\text { Dutch } \\
2,656 \\
\text { (72 per cent.) }\end{array}$ & & $\begin{array}{l}\text { Male } \\
\text { Female }\end{array}$ & $\begin{array}{r}1,967 \\
689\end{array}$ & $\begin{array}{l}74 \\
26\end{array}$ \\
\hline & $\begin{array}{l}\text { Foreign } \\
1,027 \\
\text { (28 per cent.) }\end{array}$ & $\begin{array}{l}\text { Netherlands } \\
715 \\
\text { (70 per cent.) }\end{array}$ & $\begin{array}{l}\text { Male } \\
\text { Female }\end{array}$ & $\begin{array}{r}697 \\
18\end{array}$ & $\begin{array}{r}97 \\
3\end{array}$ \\
\hline & & $\begin{array}{l}\text { Abroad } \\
147 \\
\text { (14 per cent.) }\end{array}$ & $\begin{array}{l}\text { Male } \\
\text { Female }\end{array}$ & $\begin{array}{r}146 \\
1\end{array}$ & $\begin{array}{r}99 \\
1\end{array}$ \\
\hline & & $\begin{array}{l}\text { Unknown } \\
165 \\
\text { (16 per cent.) }\end{array}$ & $\begin{array}{l}\text { Male } \\
\text { Female }\end{array}$ & $\begin{array}{r}161 \\
4\end{array}$ & $\begin{array}{r}98 \\
2\end{array}$ \\
\hline
\end{tabular}

into 70 per cent. living in the Netherlands and 30 per cent. living abroad (147) or of unknown domicile (165).

\section{Sex ratio}

Among the patients with early syphilis there were 5.5 men to 1 woman, and among those with gonorrhoea 4.2 men to 1 woman. The lower ratio among the gonorrhoea patients may be explained by the fact that seamen with gonorrhoea were often treated on board ship and do not appear in the statistics. A report by the British Co-operative Clinical Group (1968) shows a similar difference, and suggests that the high ratio in syphilis patients reflects the larger percentage of male homosexuals among the syphilitics.

\section{Number of V.D. patients by domicile and place of infection}

\section{EARLY SYPHILIS}

Fig. 2 (overleaf) shows the domicile, place of infection, and sex of the patients with early syphilis.

Among the male patients one quarter of those of Dutch nationality and of the foreigners living in the Netherlands were infected abroad. The proportion of foreigners who were unable to give the place of infection was twice as large as the corresponding group of Dutchmen. Of the remaining foreign 
patients, 7 per cent. said they had contracted early syphilis in the Netherlands and 60 per cent. abroad, 33 per cent. being unable to state the place of infection.

The foreign female patients may be ignored, since only two such cases were reported. Of the Dutch female patients, 76 per cent. said they were infected in the Netherlands and 8 per cent. abroad, and 16 per cent. did not know the place of infection.

In Fig. 3 (opposite) those with early syphilis - in so far as they lived or were infected in the Netherlandsare subdivided by municipalities. The four largest cities (Amsterdam, Rotterdam, Utrecht, and The Hague) contain only 18.7 per cent. of the total Dutch male population but 81 per cent. of men infected in the Netherlands said that they contracted early syphilis there and 59 per cent. of the Dutch male patients lived there. These percentages are even higher for the foreign male patients living in the Netherlands : 67 and 92 per cent. respectively. Among the sixty remaining foreign male patients only four said that they became infected in the Netherlands.

Among the Dutch females with early syphilis the distribution by domicile is much the same, but relatively fewer (69 per cent.) said that they were infected in the four largest cities and relatively more (15 per cent.) said that they were infected in the smaller towns with fewer than 100,000 inhabitants. This is most probably due to the fact that wives are more frequently infected by their husbands, who bring the infection home from the larger cities.

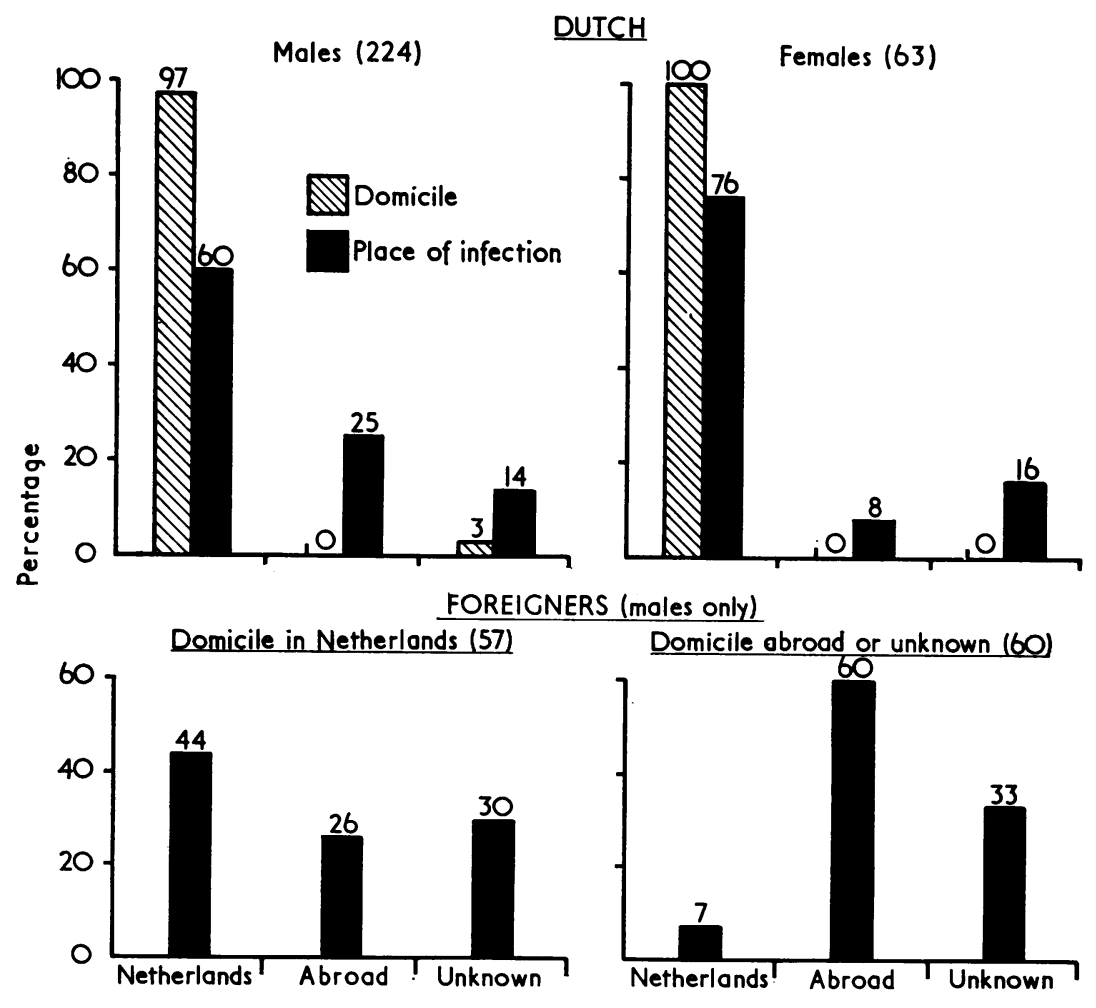

FIG. 2 Percentage patients with early syphilis, by sex, nationality, domicile, and place of infection (reported by dermatologists, 1967) 


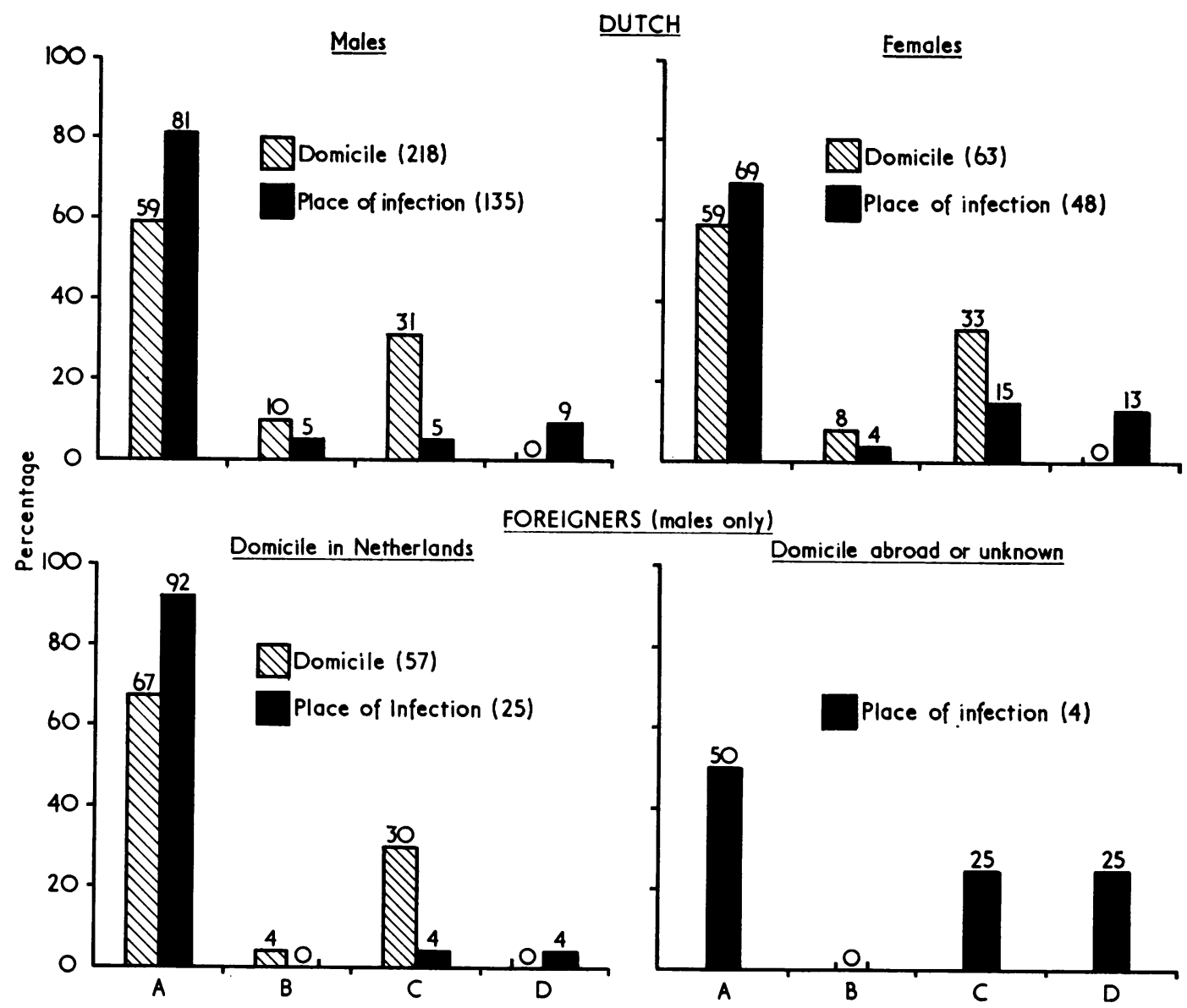

FIG. 3 Percentage patients with early syphilis, by sex, nationality, domicile in the Netherlands, and place of infection in the Netherlands, 1967

A : Four chief cities, Amsterdam, Rotterdam, Utrecht, and The Hague

$B$ : The other cities of more than 100,000 inhabitants

\section{GONORRHOEA}

Fig. 4 (overleaf) shows that more of the patients with gonorrhoea, both male and female, Dutch and foreigners are infected in the Netherlands. The foreign female patients with gonorrhoea may be ignored in view of the small number of cases (19). Thus 82 per cent. of the Dutch male patients and 88 per cent. of the foreign male patients living in the Netherlands said that they were infected in the Netherlands. Of the remaining foreign male patients 28 per cent., and of the Dutch female patients 92 per cent., said that they were infected in the Netherlands.

In Fig. 5 (overleaf) the patients with gonorrhoea in
C: Towns of less than 100,000 inhabitants

D: Not known exactly (but in Netherlands)

so far as they lived or were infected in the Netherlands are subdivided by municipalities.

Of the Dutch male patients, 64 per cent. lived in the four largest cities, and 72 per cent. of those infected in the Netherlands said that they were infected there. Of the foreign male patients living in the Netherlands, 76 per cent. lived in the four largest cities and 82 per cent. said they were infected there.

88 per cent. of the 67 other foreign male patients who were infected in the Netherlands said that they had contracted gonorrhoea in one of these four municipalities. The distribution of the Dutch females with gonorrhoea by domicile and place of infection is much the same as that of those with syphilis. 


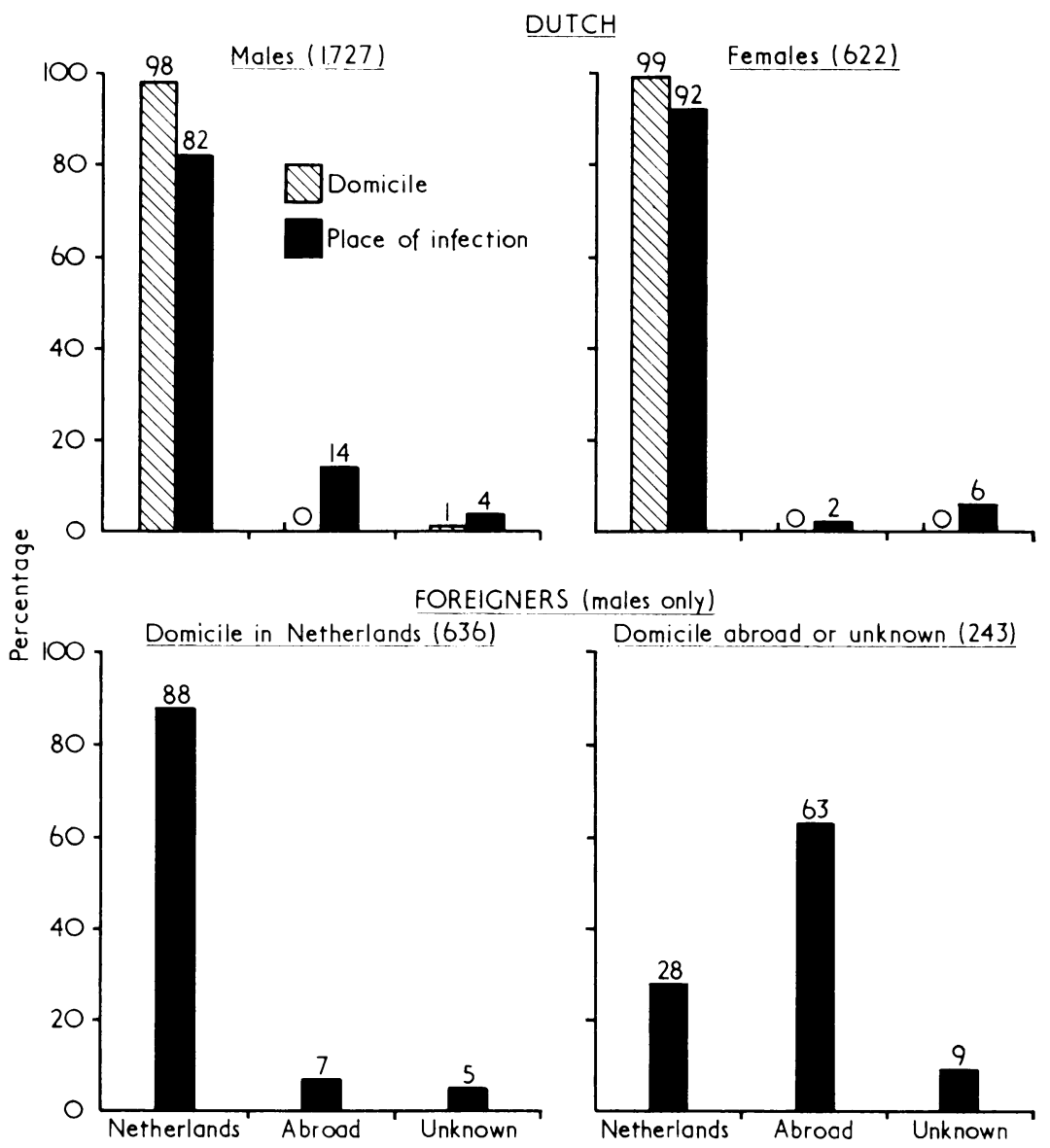

FIG. 4 Percentage patients with gonorrhoea, by sex, nationality, domicile, and place of infection (reported by dermatologists, 1967)

TABLE XI Male patients who contracted syphilis or gonorrhoea abroad, by nationality and place of infection

\begin{tabular}{|c|c|c|c|c|c|c|c|c|c|c|c|c|c|}
\hline \multirow{2}{*}{\multicolumn{2}{|c|}{ Nationality }} & \multirow{2}{*}{\multicolumn{4}{|c|}{ Dutch }} & \multicolumn{8}{|c|}{ Foreign } \\
\hline & & & & & & \multicolumn{4}{|c|}{ Domicile in the Netherlands } & \multicolumn{4}{|c|}{ Domicile abroad or unknown } \\
\hline \multicolumn{2}{|l|}{ Infection } & \multicolumn{2}{|c|}{ Syphilis } & \multicolumn{2}{|c|}{ Gonorrhoea } & \multicolumn{2}{|c|}{ Syphilis } & \multicolumn{2}{|c|}{ Gonorrhoea } & \multicolumn{2}{|c|}{ Syphilis } & \multicolumn{2}{|c|}{ Gonorrhoea } \\
\hline & & No. & Per cent. & No. & Per cent. & No. & Per cent. & No. & Per cent. & No. & Per cent. & No. & Per cent. \\
\hline \multirow{6}{*}{$\begin{array}{l}\text { Place of } \\
\text { infection }\end{array}$} & Europe & 34 & 60 & 197 & 80 & 9 & 60 & 40 & 85 & 10 & 28 & 97 & 63 \\
\hline & Africa & 5 & 9 & 8 & 3 & 3 & 20 & 3 & 6 & 7 & 19 & 8 & 5 \\
\hline & America & 16 & 28 & 22 & 9 & 3 & 20 & 1 & 2 & 16 & 44 & 39 & 25 \\
\hline & Middle East $/$ Asia & 2 & 4 & 17 & 7 & 一 & - & 3 & 6 & 3 & 8 & 9 & 6 \\
\hline & Australia/New Zealand & - & 一 & 3 & 1 & - & 一 & - & - & - & - & - & 一 \\
\hline & Total & 57 & 100 & 247 & 100 & 15 & 100 & 47 & 100 & 36 & 100 & 153 & 100 \\
\hline
\end{tabular}




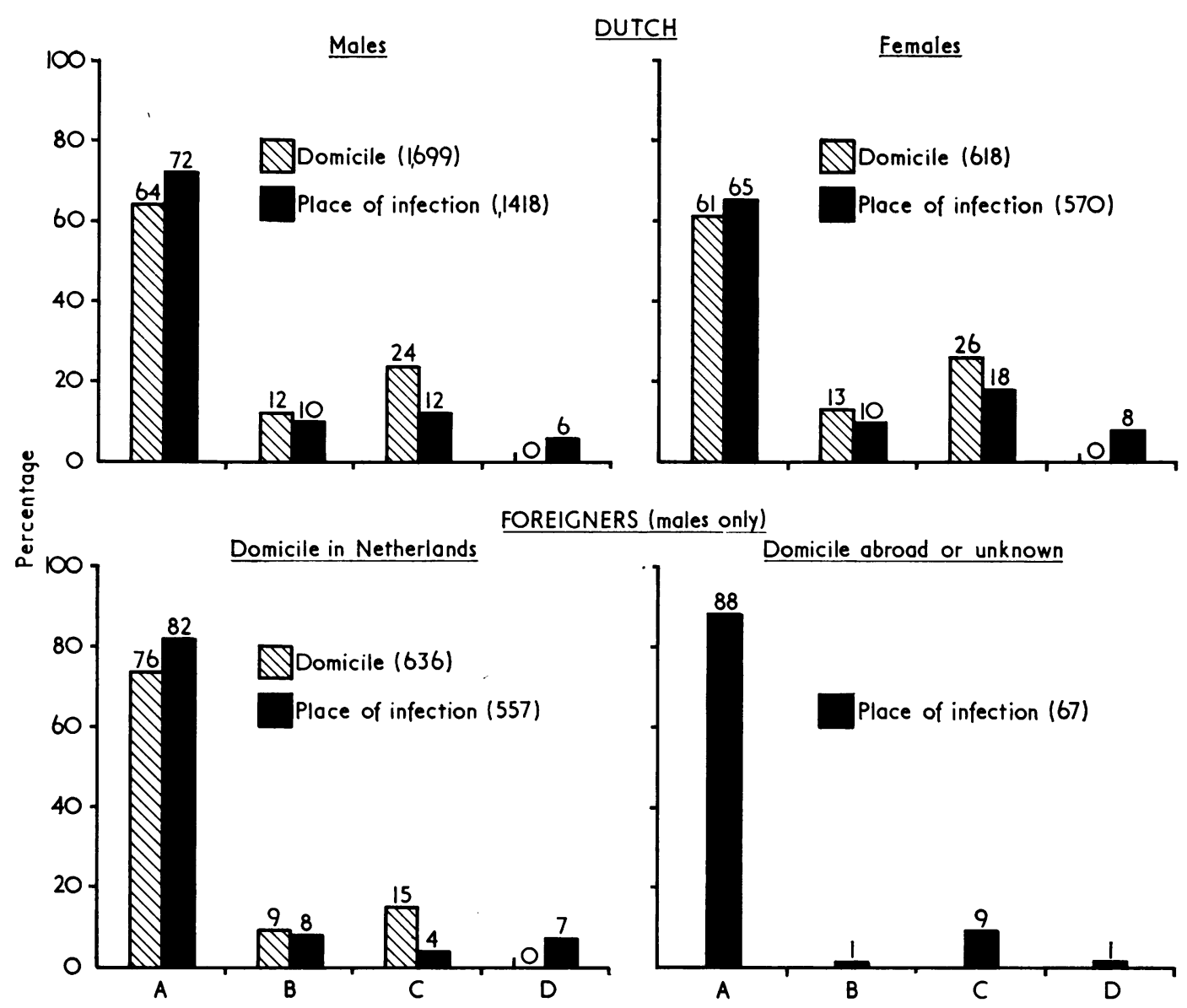

FIG. 5 Percentage patients with gonorrhoea, by sex, nationality, domicile in the Netherlands, and place of infection in the Netherlands, 1967. A, B, C, D : as in Fig. 3

\section{COMBINED}

Fig. 6 (overleaf) shows the towns where five or more patients (both Dutch and foreign) said that they had contracted early syphilis and/or gonorrhoea; the cities of Amsterdam, Rotterdam, Utrecht, and The Hague, each with more than 100 patients infected, stand out clearly as the chief centres of infection. In Table XI the female patients are omitted because they are so few.

As regards early syphilis, 60 per cent. of the Dutch and foreign patients living in the Netherlands said that they were infected in Europe. For the foreign patients, not domiciled in the Netherlands, this percentage is considerably lower (28 per cent.).

The corresponding percentages for gonorrhoea are 80,85 , and 63 per cent. respectively.
Patients analysed by age and sex

Fig. 7 (overleaf) shows a clear preponderance of the age group 20 to 29 years among both syphilis and gonorrhoea patients. With the exception of the Dutch female patients with gonorrhoea, in whom the age groups 15 to 19 and 30 to 39 years come second and third, the 30 to 39 year group comes second. The foreign male patients with both syphilis and gonorrhoea show a greater preponderance in the younger age groups.

\section{Number of patients per 100,000 inhabitants (age-specific rates)}

The national incidence of early syphilis and gonorrhoea calculated from the results of the prospective enquiry among the dermatologists is 3.5 and 26.0 per 


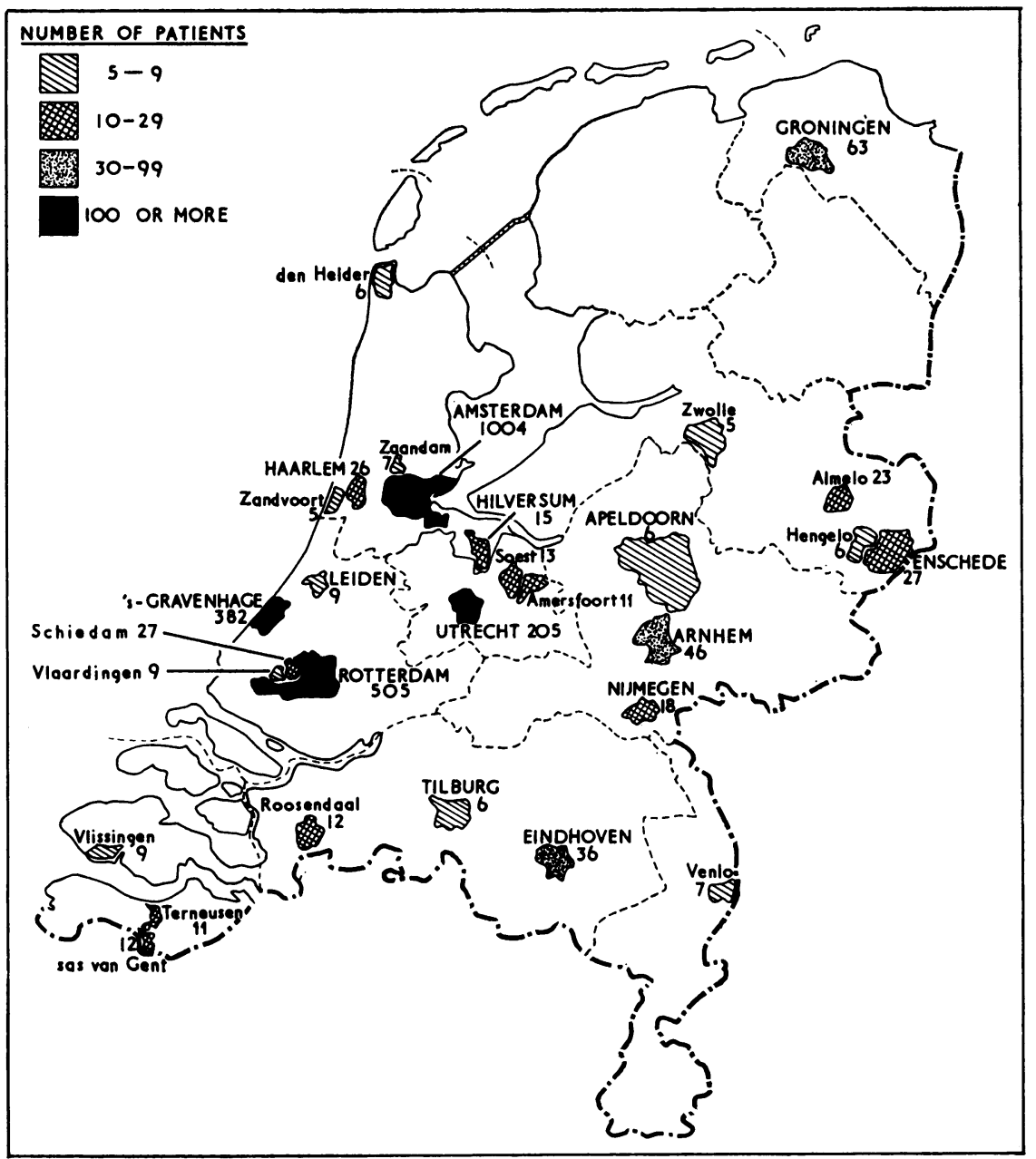

FIG. 6 Map of the Netherlands, showing towns and cities where five or more patients were infected with early (primary, secondary, or latent) syphilis and/or gonorrhoea in 1967 


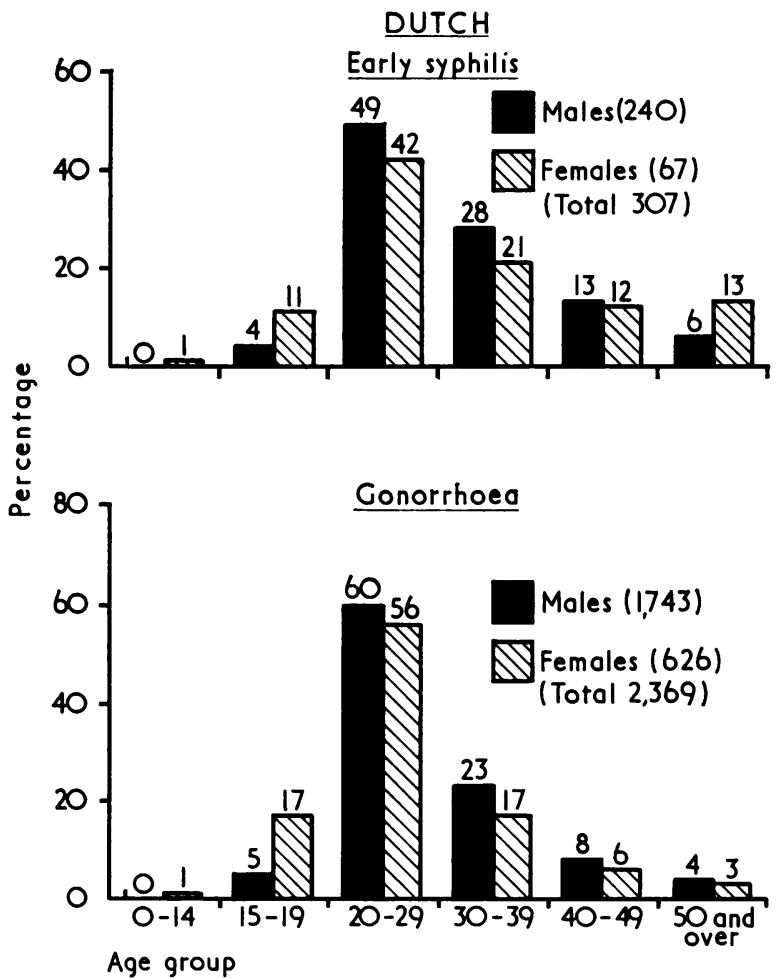

FIG. 7 Percentage patients with early syphilis or gonorrhoea, by age, sex, and nationality, reported by dermatologists in 1967 (actual total numbers in parenthesis)

100,000 respectively (Table XII, overleaf). The age group 20 to 29 years shows the highest frequency for both syphilis and gonorrhoea: 11.1 and 102.6 respectively. The incidence among males is considerably greater than among females; 5.8 and 1.1 respectively for syphilis and 41.8 and 10.3 for gonorrhoea. The highest incidence is found in the four largest cities (Table XIII). The incidence in the various age groups, especially in that of 20 to 29 years, is largely determined by the large number of foreign patients among the male patients in the four cities.

\section{Referral of patients to the dermatologists (Table XIV, overleaf)}

Of the total of 3,683 patients, 38 per cent. had been referred to the dermatologist by a general practitioner, and only 4 per cent. by a specialist other than a dermatologist; 8 per cent. were referred from some other source (e.g. by contacts), and 46 per cent. came directly. Only 4 per cent. were said to have been referred by a V.D. clinic, but of the remaining
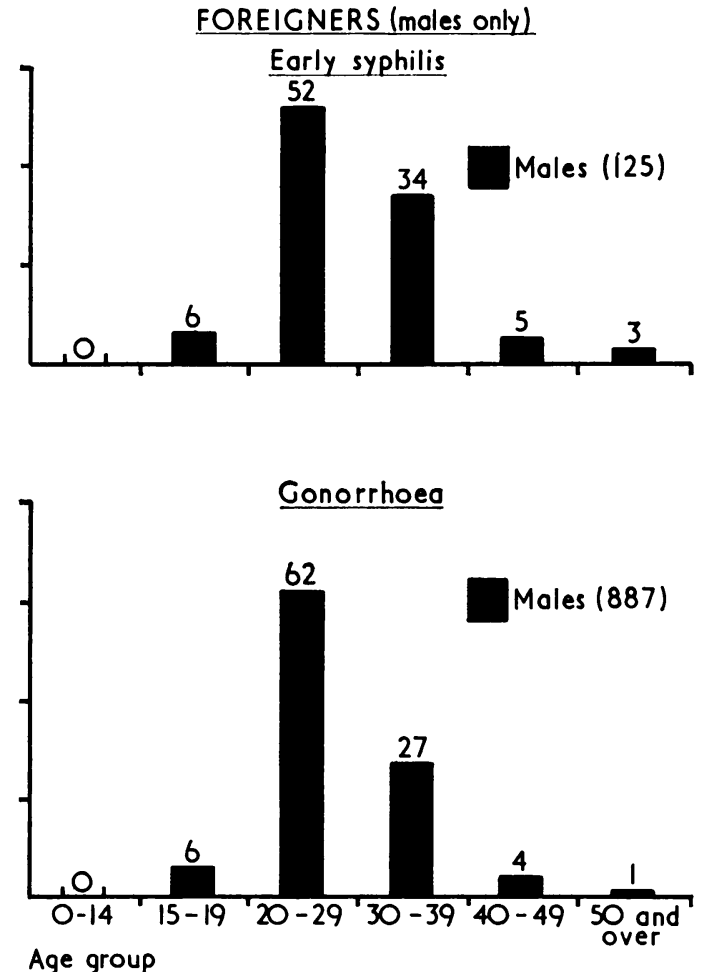

TABLE XIII Patients with syphilis or gonorrhoea, by sex and domicile in the Netherlands

\begin{tabular}{|c|c|c|c|}
\hline Diagnosis & Sex & Domicile & $\begin{array}{l}\text { Incidence } \\
\text { per } 100,000 \\
\text { population }\end{array}$ \\
\hline \multirow[t]{2}{*}{$\begin{array}{l}\text { Early syphilis } \\
436\end{array}$} & Male 365 & $\begin{array}{l}\text { Amsterdam } \\
\text { Rotterdam } \\
\text { The Hague } \\
\text { Utrecht } \\
\text { Rest of the } \\
\text { country }\end{array}$ & $\begin{array}{r}22 \cdot 6 \\
24 \cdot 3 \\
12 \cdot 5 \\
14 \cdot 0 \\
2 \cdot 6\end{array}$ \\
\hline & Female 71 & $\begin{array}{l}\text { Amsterdam } \\
\text { Rotterdam } \\
\text { The Hague } \\
\text { Utrecht } \\
\text { Rest of the } \\
\text { country }\end{array}$ & $\begin{array}{l}3 \cdot 4 \\
3 \cdot 1 \\
2 \cdot 6 \\
5 \cdot 0 \\
\\
0.6\end{array}$ \\
\hline \multirow[t]{2}{*}{$\begin{array}{l}\text { Gonorrhoea } \\
3,277\end{array}$} & Male 2,630 & $\begin{array}{l}\text { Amsterdam } \\
\text { Rotterdam } \\
\text { The Hague } \\
\text { Utrecht } \\
\text { Rest of the } \\
\text { country }\end{array}$ & $\begin{array}{c}167 \cdot 9 \\
160 \cdot 4 \\
115 \cdot 0 \\
170 \cdot 2 \\
\\
16 \cdot 1\end{array}$ \\
\hline & Female 647 & $\begin{array}{l}\text { Amsterdam } \\
\text { Rotterdam } \\
\text { The Hague } \\
\text { Utrecht } \\
\text { Rest of the } \\
\text { country }\end{array}$ & $\begin{array}{l}29 \cdot 3 \\
39 \cdot 1 \\
24 \cdot 7 \\
33 \cdot 2 \\
5 \cdot 1\end{array}$ \\
\hline
\end{tabular}


TABLE XII Incidence per 100,000 population of patients with syphilis ${ }^{1,2}$ or gonorrhoea, ${ }^{2}$ by sex, domicile, ${ }^{3}$ nationality, and age (age-specific rates)

\begin{tabular}{|c|c|c|c|c|c|c|c|c|c|c|c|c|c|c|c|c|}
\hline \multicolumn{3}{|l|}{ Infection } & \multicolumn{7}{|c|}{ Syphilis } & \multicolumn{7}{|c|}{ Gonorrhoea } \\
\hline \multicolumn{3}{|c|}{ Age group (yrs) } & \multirow[t]{2}{*}{$0-14$} & \multirow[t]{2}{*}{ 15-19 } & \multirow[t]{2}{*}{$20-29$} & \multirow[t]{2}{*}{$30-39$} & \multirow{2}{*}{$40-49$} & \multirow{2}{*}{$\begin{array}{l}50 \\
\text { and } \\
\text { over }\end{array}$} & \multirow[t]{2}{*}{ Total } & \multirow[t]{2}{*}{$0-14$} & \multirow[t]{2}{*}{$15-19$} & \multirow[t]{2}{*}{$20-29$} & \multirow[t]{2}{*}{$30-39$} & \multirow{2}{*}{$40-49$} & \multirow{2}{*}{$\begin{array}{l}50 \\
\text { and } \\
\text { over }\end{array}$} & \multirow[t]{2}{*}{ Total } \\
\hline Nationality & Domicile & Sex & & & & & & & & & & & & & & \\
\hline \multirow[t]{4}{*}{ Dutch } & $\begin{array}{l}\text { Amsterdam, Rotterdam } \\
\text { Hague, Utrecht }\end{array}$ & $\begin{array}{l}\text { Male } \\
\text { Female }\end{array}$ & $\overline{1 \cdot 2}$ & $\begin{array}{l}2 \cdot 0 \\
3 \cdot 1\end{array}$ & $\begin{array}{r}32 \cdot 7 \\
9 \cdot 8\end{array}$ & $\begin{array}{r}32 \cdot 9 \\
4 \cdot 4\end{array}$ & $\begin{array}{l}9 \cdot 7 \\
2 \cdot 5\end{array}$ & $\begin{array}{l}3 \cdot 0 \\
1 \cdot 7\end{array}$ & $\begin{array}{r}11 \cdot 6 \\
3 \cdot 1\end{array}$ & $\begin{array}{l}1 \cdot 1 \\
3 \cdot 5\end{array}$ & $\begin{array}{l}56 \cdot 5 \\
60 \cdot 3\end{array}$ & $\begin{array}{l}3403 \\
119 \cdot 2\end{array}$ & $\begin{array}{r}181 \cdot 9 \\
48 \cdot 0\end{array}$ & $\begin{array}{l}59 \cdot 0 \\
11 \cdot 3\end{array}$ & $\begin{array}{r}10 \cdot 4 \\
3 \cdot 9\end{array}$ & $\begin{array}{l}93 \cdot 2 \\
30 \cdot 6\end{array}$ \\
\hline & Other municipalities & $\begin{array}{l}\text { Male } \\
\text { Female }\end{array}$ & 二 & $\begin{array}{l}1.7 \\
0.9\end{array}$ & $\begin{array}{l}6 \cdot 6 \\
1 \cdot 4\end{array}$ & $\begin{array}{l}3 \cdot 2 \\
1 \cdot 3\end{array}$ & $\begin{array}{l}3 \cdot 1 \\
0 \cdot 7\end{array}$ & $\begin{array}{l}0 \cdot 4 \\
0 \cdot 2\end{array}$ & $\begin{array}{l}2 \cdot 0 \\
0 \cdot 6\end{array}$ & $\overline{0.4}$ & $\begin{array}{r}7 \cdot 2 \\
10 \cdot 5\end{array}$ & $\begin{array}{l}47 \cdot 7 \\
17 \cdot 6\end{array}$ & $\begin{array}{r}22 \cdot 6 \\
6 \cdot 6\end{array}$ & $\begin{array}{r}10 \cdot 8 \\
3 \cdot 4\end{array}$ & $\begin{array}{l}2 \cdot 7 \\
0 \cdot 4\end{array}$ & $\begin{array}{r}12 \cdot 7 \\
4 \cdot 9\end{array}$ \\
\hline & Total Netherlands & $\begin{array}{l}\text { Male } \\
\text { Female }\end{array}$ & $\overline{0.2}$ & $\begin{array}{l}1 \cdot 7 \\
1 \cdot 3\end{array}$ & $\begin{array}{r}11 \cdot 9 \\
3 \cdot 1\end{array}$ & $\begin{array}{l}8.5 \\
1.8\end{array}$ & $\begin{array}{l}4 \cdot 5 \\
1 \cdot 1\end{array}$ & $\begin{array}{l}1.0 \\
0.6\end{array}$ & $\begin{array}{l}3 \cdot 8 \\
1 \cdot 1\end{array}$ & $\begin{array}{l}0.2 \\
0.9\end{array}$ & $\begin{array}{l}15 \cdot 7 \\
19.2\end{array}$ & $\begin{array}{r}106 \cdot 1 \\
37 \cdot 9\end{array}$ & $\begin{array}{l}50 \cdot 8 \\
14 \cdot 0\end{array}$ & $\begin{array}{r}20 \cdot 5 \\
5 \cdot 1\end{array}$ & $\begin{array}{l}4.5 \\
1 \cdot 3\end{array}$ & $\begin{array}{r}27 \cdot 7 \\
9 \cdot 9\end{array}$ \\
\hline & & Total & $0 \cdot 1$ & 1.5 & $7 \cdot 6$ & $5 \cdot 2$ & $2 \cdot 7$ & $0 \cdot 8$ & $2 \cdot 4$ & 0.5 & $17 \cdot 4$ & $73 \cdot 1$ & $32 \cdot 8$ & $12 \cdot 7$ & $2 \cdot 8$ & 18.8 \\
\hline \multirow[t]{4}{*}{ Foreign } & $\begin{array}{l}\text { Amsterdam, Rotterdam } \\
\text { Hague, Utrecht }\end{array}$ & $\begin{array}{l}\text { Male } \\
\text { Female }\end{array}$ & 二 & $\frac{5 \cdot 0}{-}$ & $\begin{array}{r}25 \cdot 1 \\
0.5\end{array}$ & $23 \cdot 6$ & $\begin{array}{l}4 \cdot 2 \\
0 \cdot 6\end{array}$ & 0.9 & $\begin{array}{l}8 \cdot 2 \\
0 \cdot 2\end{array}$ & - & $\begin{array}{r}45 \cdot 6 \\
1 \cdot 0\end{array}$ & $\begin{array}{r}230 \cdot 2 \\
4.9\end{array}$ & $\begin{array}{r}129.6 \\
-\end{array}$ & $\begin{array}{r}13 \cdot 2 \\
0.6\end{array}$ & $\frac{1.5}{-}$ & $\begin{array}{r}60.5 \\
0.9\end{array}$ \\
\hline & Other municipalities & $\begin{array}{l}\text { Male } \\
\text { Female }\end{array}$ & 二 & $\stackrel{0 \cdot 4}{-}$ & $\begin{array}{l}2 \cdot 0 \\
0 \cdot 1\end{array}$ & $\begin{array}{l}1 \cdot 5 \\
0 \cdot 2\end{array}$ & 二 & $\frac{0 \cdot 1}{-}$ & $\begin{array}{l}0.6 \\
0.0\end{array}$ & $\overline{-}$ & $\begin{array}{l}1 \cdot 4 \\
0.2\end{array}$ & $\begin{array}{r}12 \cdot 0 \\
0.8\end{array}$ & $\begin{array}{l}8.6 \\
0.3\end{array}$ & $\begin{array}{l}2 \cdot 8 \\
0 \cdot 2\end{array}$ & $\underline{0.2}$ & $\begin{array}{l}3 \cdot 4 \\
0 \cdot 2\end{array}$ \\
\hline & Total Netherlands & $\begin{array}{l}\text { Male } \\
\text { Female }\end{array}$ & 二 & $1 \cdot 2$ & $\begin{array}{l}6 \cdot 6 \\
0 \cdot 2\end{array}$ & $\begin{array}{l}5 \cdot 4 \\
0 \cdot 1\end{array}$ & $\begin{array}{l}0.8 \\
0 \cdot 1\end{array}$ & $\frac{0.3}{-}$ & $\begin{array}{l}2 \cdot 0 \\
0 \cdot 1\end{array}$ & 二 & $\begin{array}{l}9 \cdot 1 \\
0 \cdot 4\end{array}$ & $\begin{array}{r}55 \cdot 6 \\
1 \cdot 6\end{array}$ & $\begin{array}{r}30 \cdot 0 \\
0 \cdot 3\end{array}$ & $\begin{array}{l}4 \cdot 9 \\
0.3\end{array}$ & 0.5 & $\begin{array}{r}14 \cdot 1 \\
0 \cdot 3\end{array}$ \\
\hline & & Total & 一 & $0 \cdot 6$ & 3.5 & $2 \cdot 8$ & 0.5 & $0 \cdot 1$ & $1 \cdot 0$ & - & $4 \cdot 4$ & $29 \cdot 5$ & $15 \cdot 4$ & $2 \cdot 5$ & $0 \cdot 2$ & $7 \cdot 2$ \\
\hline \multirow[t]{4}{*}{ All } & $\begin{array}{l}\text { Amsterdam, Rotterdam } \\
\text { Hague, Utrecht }\end{array}$ & $\begin{array}{l}\text { Male } \\
\text { Female }\end{array}$ & $\overline{1 \cdot 2}$ & $\begin{array}{l}6 \cdot 9 \\
3 \cdot 1\end{array}$ & $\begin{array}{l}57 \cdot 8 \\
10 \cdot 4\end{array}$ & $\begin{array}{r}56 \cdot 6 \\
4 \cdot 4\end{array}$ & $\begin{array}{r}13 \cdot 9 \\
3 \cdot 1\end{array}$ & $\begin{array}{l}4 \cdot 0 \\
1 \cdot 7\end{array}$ & $\begin{array}{r}19 \cdot 7 \\
3.3\end{array}$ & $\begin{array}{l}1 \cdot 1 \\
3.5\end{array}$ & $\begin{array}{r}102 \cdot 1 \\
61 \cdot 3\end{array}$ & $\begin{array}{l}570 \cdot 5 \\
124 \cdot 1\end{array}$ & $\begin{array}{r}311 \cdot 5 \\
48 \cdot 0\end{array}$ & $\begin{array}{l}72 \cdot 2 \\
12 \cdot 0\end{array}$ & $\begin{array}{r}11.9 \\
3.9\end{array}$ & $\begin{array}{r}153.7 \\
31.5\end{array}$ \\
\hline & Other municipalities & $\begin{array}{l}\text { Male } \\
\text { Female }\end{array}$ & 二 & $\begin{array}{l}2 \cdot 1 \\
0.9\end{array}$ & $\begin{array}{l}8.7 \\
1.5\end{array}$ & $\begin{array}{l}4 \cdot 8 \\
1 \cdot 4\end{array}$ & $\begin{array}{l}3.1 \\
0.7\end{array}$ & $\begin{array}{l}0.5 \\
0.2\end{array}$ & $\begin{array}{l}2.6 \\
0.6\end{array}$ & $\overline{0.4}$ & $\begin{array}{r}8.7 \\
10.7\end{array}$ & $\begin{array}{l}59 \cdot 7 \\
18 \cdot 4\end{array}$ & $\begin{array}{r}31.2 \\
6.9\end{array}$ & $\begin{array}{r}13 \cdot 6 \\
3 \cdot 6\end{array}$ & $\begin{array}{l}2 \cdot 9 \\
0 \cdot 4\end{array}$ & $\begin{array}{r}16 \cdot 1 \\
5 \cdot 1\end{array}$ \\
\hline & Total Netherlands & $\begin{array}{l}\text { Male } \\
\text { Female }\end{array}$ & $\overline{0.2}$ & $\begin{array}{l}2 \cdot 9 \\
1 \cdot 3\end{array}$ & $\begin{array}{r}18 \cdot 5 \\
3 \cdot 3\end{array}$ & $\begin{array}{r}13.9 \\
2.0\end{array}$ & $\begin{array}{l}5 \cdot 3 \\
1 \cdot 2\end{array}$ & $\begin{array}{l}1.3 \\
0.6\end{array}$ & $\begin{array}{l}5 \cdot 8 \\
1 \cdot 1\end{array}$ & $\begin{array}{l}0.2 \\
0.9\end{array}$ & $\begin{array}{l}24 \cdot 8 \\
19 \cdot 6\end{array}$ & $\begin{array}{r}161.7 \\
39.5\end{array}$ & $\begin{array}{l}80 \cdot 8 \\
14 \cdot 3\end{array}$ & $\begin{array}{r}25.4 \\
5 \cdot 4\end{array}$ & $\begin{array}{l}5.0 \\
1.3\end{array}$ & $\begin{array}{l}41 \cdot 8 \\
10 \cdot 3\end{array}$ \\
\hline & & Total & $0 \cdot 1$ & $2 \cdot 1$ & $11 \cdot 1$ & $8 \cdot 1$ & $3 \cdot 2$ & 0.9 & 3.5 & 0.5 & $22 \cdot 2$ & $102 \cdot 6$ & $48 \cdot 2$ & $15 \cdot 2$ & 3.0 & $26 \cdot 0$ \\
\hline
\end{tabular}

1. Primary, secondary, or early latent syphilis.

2. Patients with both early syphilis and gonorrhoea (mixed infections) have been included in both under early syphilis and under gonorrhoea.

3. In principle the domicile of the patients in the Netherlands has been taken for distribution by municipality group; if, however, patients are living abroad or their domicile is unknown, the municipality in which the dermatologist has diagnosed the disease has been taken.

4. Including patients living in the Netherlands whose exact domicile (municipality) is not known.

TABLE XIV Referral of patients with venereal disease to a dermatologist

\begin{tabular}{lccc}
\hline \multirow{2}{*}{ Referred by } & \multicolumn{2}{c}{ Patients reported by dermatologists } \\
\cline { 3 - 4 } & & No. & Per cent. \\
\cline { 3 - 3 } & & 1,403 & 38 \\
General practitioner & 141 & 4 \\
Specialist & 160 & 4 \\
V.D. clinic & 285 & 8 \\
Other source & & 1,694 & 46 \\
\cline { 3 - 4 } Not referred & & 3,683 & 100 \\
\cline { 3 - 4 } Total & & 2,120 & 58 \\
\hline No. known to V.D. clinics & &
\end{tabular}

patients referred to the dermatologist and of the non-referred patients, 58 per cent. proved to be known to a V.D. clinic. If the patients are then subdivided into Dutch and foreigners, 50 per cent. of the 2,656 Dutch patients ( 1,325 cases) and 77 per cent. of the 1,027 foreign patients (795 cases) were known to the V.D. clinics. A comparison of Fig. 1 and Fig. 6 clearly shows that the few remaining clinics are situated in the large cities where most of the cases of venereal disease originate.

\section{Source of infection (Table $X V$, opposite) DUTCH NATIONALS}

Of the married Dutch patients, 21 per cent. of the males and 53 per cent. of the females were infected by the husband or wife; 28 per cent. of the males stated that they had contracted the disease from a prostitute and 2 per cent. from a homosexual partner.

Of the unmarried Dutch patients with a regular partner, 64 per cent. of the males and 85 per cent. of the females said that they had been infected by 'another' regular partner, but the wording of the questionnaire was ambiguous. 5 per cent. of the males said that they were infected by a prostitute and 15 per cent. by a homosexual partner.

Of the other unmarried Dutch males, 25 per cent. said that they had contracted the disease from a prostitute and 20 per cent. from a homosexual contact. 
TABLE XV Percentage patients with venereal disease $e^{1}$, by nationality, sex, marital status, and source of infection

\begin{tabular}{|c|c|c|c|c|c|c|c|c|c|c|c|c|}
\hline \multirow{4}{*}{ Nationality } & \multirow{4}{*}{ Source of infection } & & \multicolumn{10}{|c|}{ Marital status } \\
\hline & & & \multirow{2}{*}{\multicolumn{2}{|c|}{ Married }} & \multicolumn{4}{|c|}{ Unmarried } & \multirow{2}{*}{\multicolumn{2}{|c|}{ Not knozon }} & \multirow{2}{*}{\multicolumn{2}{|c|}{ Total }} \\
\hline & & & & & \multicolumn{2}{|c|}{$\begin{array}{l}\text { Regular } \\
\text { partner }\end{array}$} & \multicolumn{2}{|c|}{$\begin{array}{l}\text { Regular partner } \\
\text { denied or } \\
\text { not known }\end{array}$} & & & & \\
\hline & & & Male & Female & Male & Female & Male & Female & Male & Female & Male & Female \\
\hline \multirow[t]{2}{*}{ Dutch } & \multicolumn{2}{|l|}{$\begin{array}{l}\text { Marriage partner } \\
\text { Other regular partner } \\
\text { Prostitute } \\
\text { Homosexual partner } \\
\text { Not precisely defined } \\
\text { Combination of partners } \\
\text { Not known }\end{array}$} & $\begin{array}{r}21 \\
3 \\
28 \\
2 \\
26 \\
2 \\
19\end{array}$ & $\begin{array}{r}53 \\
6 \\
- \\
16 \\
0 \\
24\end{array}$ & $\begin{array}{r}-64 \\
5 \\
15 \\
11 \\
0 \\
5\end{array}$ & $\frac{-}{\frac{85}{6}}$ & $\begin{array}{r}- \\
25 \\
20 \\
34 \\
0 \\
21\end{array}$ & $\frac{-}{\overline{1}}$ & $\begin{array}{l}- \\
\overline{40} \\
20 \\
\frac{20}{20}\end{array}$ & $\begin{array}{l}- \\
z \\
z\end{array}$ & $\begin{array}{l}6 \\
10 \\
23 \\
13 \\
28 \\
1 \\
18\end{array}$ & $\begin{array}{r}23 \\
29 \\
0 \\
25 \\
0 \\
23\end{array}$ \\
\hline & Total & $\begin{array}{l}\text { Per cent. } \\
\text { No. }\end{array}$ & $\begin{array}{l}100 \\
584\end{array}$ & $\begin{array}{l}100 \\
294\end{array}$ & $\begin{array}{l}100 \\
296\end{array}$ & $\begin{array}{l}100 \\
212\end{array}$ & $\begin{array}{r}100 \\
1,082\end{array}$ & $\begin{array}{l}100 \\
183\end{array}$ & $\begin{array}{r}100 \\
5\end{array}$ & - & $\begin{array}{r}100 \\
1,967\end{array}$ & $\begin{array}{l}100 \\
689\end{array}$ \\
\hline \multirow[t]{2}{*}{ Foreign } & \multicolumn{2}{|l|}{$\begin{array}{l}\text { Marriage partner } \\
\text { Other regular partner } \\
\text { Prostitute } \\
\text { Homosexual partner } \\
\text { Not precisely defined } \\
\text { Combination of partners } \\
\text { Not known }\end{array}$} & $\begin{array}{r}5 \\
1 \\
48 \\
\frac{10}{36}\end{array}$ & $\frac{44}{-}$ & $\begin{array}{r}-62 \\
7 \\
3 \\
13 \\
-15\end{array}$ & $\frac{\overline{57}}{\frac{14}{-}}$ & $\begin{array}{r}- \\
43 \\
3 \\
16 \\
0 \\
37\end{array}$ & $\begin{array}{l}- \\
\overline{17} \\
\frac{-}{83}\end{array}$ & $\begin{array}{l}- \\
\overline{56} \\
\frac{-}{44}\end{array}$ & $\begin{array}{l}- \\
\bar{Z} \\
\overline{100}\end{array}$ & $\begin{array}{r}1 \\
4 \\
42 \\
2 \\
14 \\
0 \\
36\end{array}$ & $\begin{array}{r}17 \\
17 \\
4 \\
\frac{9}{52}\end{array}$ \\
\hline & Total & $\begin{array}{l}\text { Per cent. } \\
\text { No. }\end{array}$ & $\begin{array}{l}100 \\
269\end{array}$ & $\begin{array}{r}100 \\
9\end{array}$ & $\begin{array}{r}100 \\
61\end{array}$ & $\begin{array}{r}100 \\
7\end{array}$ & $\begin{array}{l}100 \\
649\end{array}$ & $\begin{array}{r}100 \\
6\end{array}$ & $\begin{array}{r}100 \\
25\end{array}$ & $\begin{array}{r}100 \\
1\end{array}$ & $\begin{array}{r}100 \\
1,004\end{array}$ & $\begin{array}{r}100 \\
23\end{array}$ \\
\hline
\end{tabular}

1. All patients together

2. Person with whom an intimate relationship exists.

3. The particular question in the questionnaire does not permit of distinguishing for the unmarried patients between the regular partner and another regular partner.

Among the female patients homosexuality was of little significance; only one female patient gave a homosexual contact as the source of infection.

Of the total number of Dutch patients, 6 per cent. of the 1,967 males were infected by their wife, 10 per cent. by another regular partner, 23 per cent. by a prostitute and 13 per cent. by a homosexual partner. Of the 689 females, 23 per cent. were infected by their husband and 29 per cent. by another regular partner.

The partner responsible for the venereal disease in 28 per cent. of the males and 25 per cent. of the females was not further defined. In 18 per cent. of the males and 23 per cent. of the females, the source of infection was not known.

\section{FOREIGNERS}

Among the foreign male patients, infection by prostitutes was more frequent. Of the 269 married males, 48 per cent. were infected by prostitutes, of the 61 unmarried males with a regular partner 7 per cent., and of the remaining 649 unmarried males 43 per cent.

Homosexuality was mentioned by the foreigners much more rarely as the source of infection, but this does not mean that it is necessarily much less frequent.

\section{ALL MALES}

Table XVI (overleaf) shows the age and type of infection of male patients infected by prostitutes and homosexual partners. Of 224 Dutch patients with early syphilis, 38 per cent. were listed as homosexual; in the age groups 30 to 39 years and 40 to 49 years the proportion was 48 per cent. Prostitutes were the source of infection in 24 per cent. of the patients; in the age group 20 to 29 years the proportion was 32 per cent. Of the 1,727 Dutch patients with gonorrhoea 10 per cent. were infected by homosexual contacts and 23 per cent. by prostitutes.

Among the 1,004 foreign male patients, 42 per cent. were infected by prostitutes and only 2 per cent. by homosexual contacts.

\section{The problem of repeaters}

Fig. 8 (overleaf) shows that 24 per cent. of the Dutch patients with syphilis and 36 per cent. of those with gonorrhoea must be regarded as repeaters, and that male repeaters are twice as numerous as females. 
TABLE XVI Male patients infected by prostitutes or homosexual partners, by age group and nationality

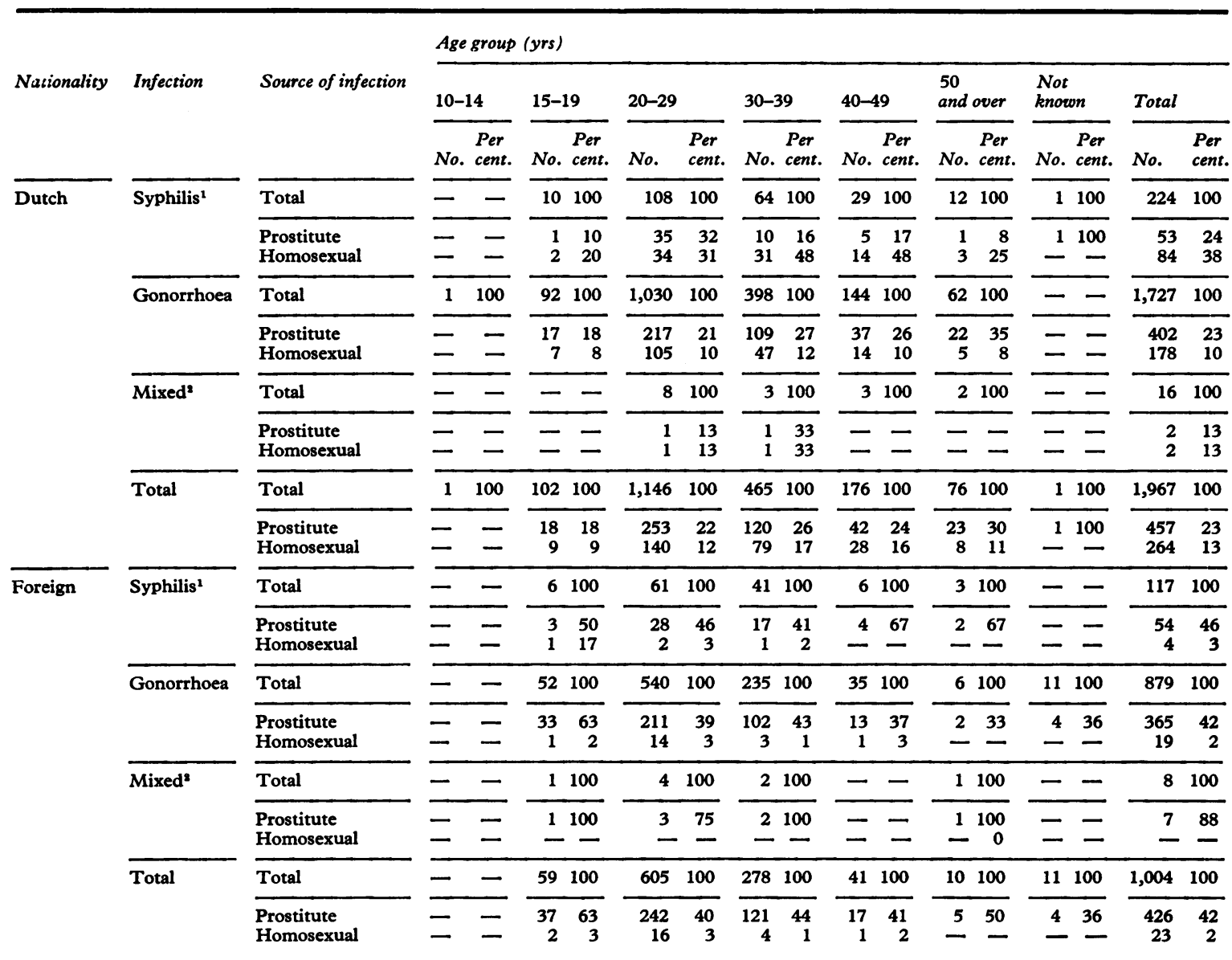

1. Primary, secondary, or early latent syphilis.

2. Early syphilis and gonorrhoea.

The largest proportion of repeaters were those with a history of gonorrhoea. It is possible that syphilis patients with a previous history of syphilis were in fact defaulters. Although the percentages of foreign repeaters are similar to those of Dutch nationals, the actual numbers are probably higher, because of the difficulty of obtaining an accurate history.

\section{Conclusions}

The following information has emerged from the results of this enquiry:
(1) Most patients live and become infected in the four largest municipalities, Amsterdam, Rotterdam, Utrecht, and The Hague, especially the first two.

(2) Foreigners, notably those employed in the Netherlands, and seafarers form a highly vulnerable group.

(3) Male homosexuals run a grave risk of contracting V.D.

(4) Prostitutes are still an important source of infection.

(5) The patients include a large number of repeaters. 


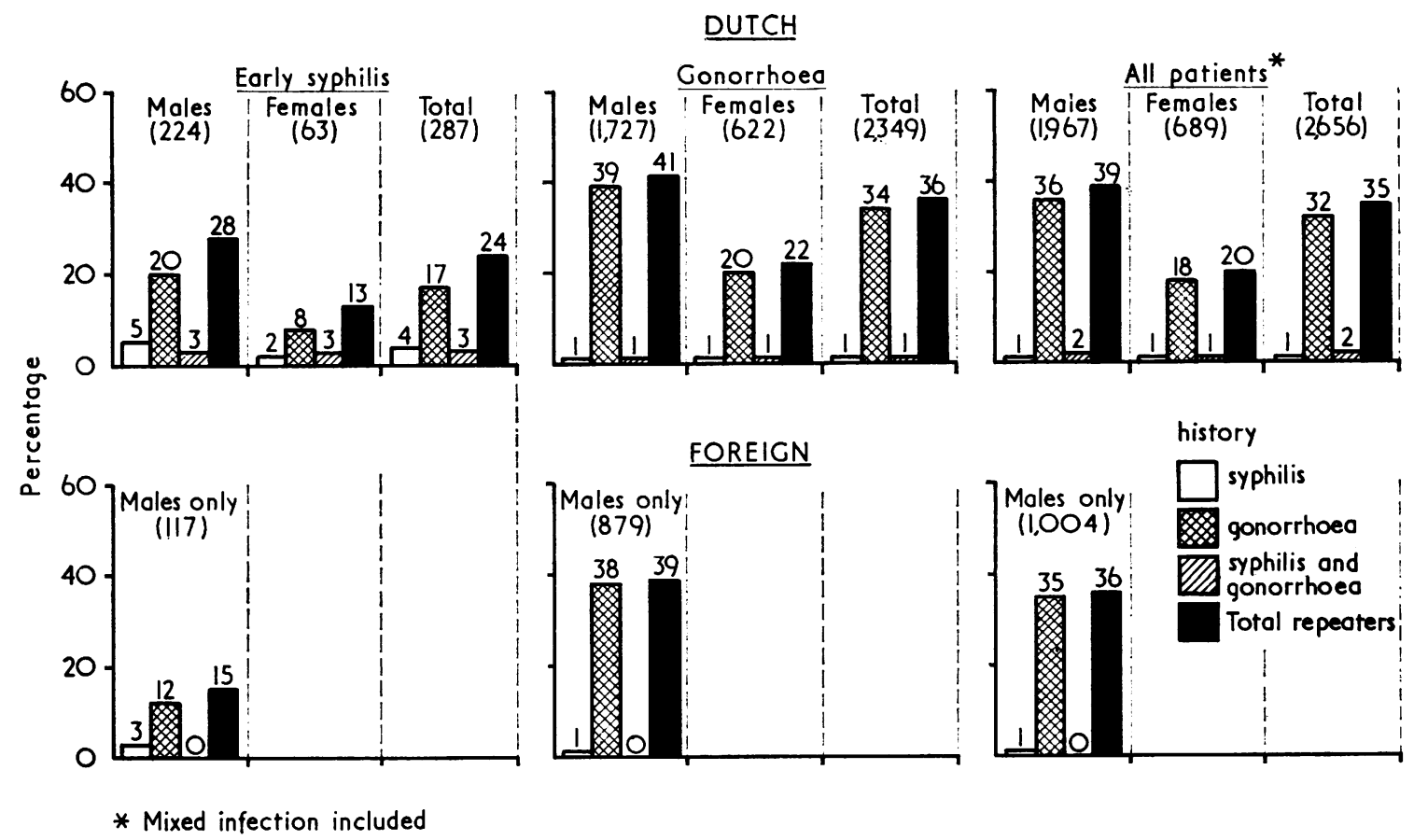

FIG. 8 Percentage patients with previous history of syphilis and/or gonorrhoea ('repeaters'), by nationality and sex, reported by dermatologists in 1967 (actual total numbers in parenthesis) 